Department of Economics- FEA/USP

Family control, pyramidal ownership and investment-cash flow sensitivity: evidence from an emerging economy

Aquiles Kalatzis

Aline Pellicani

DANTE Mendes AldRighi

WORKING PAPER SERIES № 2019-12 


\title{
Family control, pyramidal ownership and investment-cash flow sensitivity: evidence from an emerging economy
}

\author{
Aquiles Kalatzis \\ Aline Pellicani \\ Dante Mendes Aldrighi (aldrighi@usp.br)
}

\begin{abstract}
:
We investigate the effect of pyramidal ownership and family control in investment-cash flow sensitivity of Brazilian firms using financial constraint indexes to a priori classify firms. For constrained firms, we find that family control does not directly influence the investment-cash flow sensitivity, while for unconstrained firms, Family control shows a negative effect in investment decisions. However, the active involvement of the controlling family in the board increases investment-cash flow of unconstrained firms, possibly aggravating agency problems. Regarding the pyramidal ownership, we provide evidences consistent with the idea of internal transfer of funds among firms belonged to the arrangement structure.
\end{abstract}

Keywords: pyramid; family control; investment-cash flow sensitivity; financial constraint.

JEL Codes: G30; G32. 


\title{
Family control, pyramidal ownership and investment-cash flow sensitivity: evidence from an emerging economy
}

\begin{abstract}
We investigate the effect of pyramidal ownership and family control in investment-cash flow sensitivity of Brazilian firms using financial constraint indexes to a priori classify firms. For constrained firms, we find that family control does not directly influence the investment-cash flow sensitivity, while for unconstrained firms, family control shows a negative effect in investment decisions. However, the active involvement of the controlling family in the board increases investment-cash flow of unconstrained firms, possibly aggravating agency problems. Regarding the pyramidal ownership, we provide evidences consistent with the idea of internal transfer of funds among firms belonged to the arrangement structure.
\end{abstract}

Keywords: pyramid; family control; investment-cash flow sensitivity; financial constraint.

JEL Classification: G30, G32 


\section{Introduction}

Corporate finance literature intensively explores how investment and financing are related per se (Ağca and Mozumdar 2017). Following Fazzari, Hubbard and Petersen (1988), a widely number of papers examines the sensitivity of investment to cash flow (Hubbard 1998), mainly focusing on how this sensitivity differs among groups with similar features, such as size, age, dividend payout and ownership structure (Kadapakkam, Kumar, and Riddick 1998; Devereux and Schiantarelli 1990; Guariglia 2008; Fazzari, Hubbard, and Petersen 1988; Hoshi, Kashyap, and Scharfstein 1991, among others). Specially in the ownership and control structure context, the primary interest is to understand how the conflicts of interest that potentially drives the linkage between large shareholders, minority shareholders, managers and stakeholders may harm firm's investment decisions. To examine the relation between large shareholders and corporate investment, many papers focus on family ownership, since families constitute a relevant part of large shareholders around the world (La Porta et al. 1999; Faccio and Lang 2002; Claessens and Yurtoglu 2013). Further, family owners can maintain their control over an organization by a chain of ownership relations (Almeida and Wolfenzon 2006), creating a business group which is referred to the literature as pyramidal structure.

In this paper, we explore the relation between family control, pyramidal ownership and investment decisions, focusing on the effect, if any, of such ownership structures in the investment-cash flow sensitivity of Brazilian traded firms. Previous studies have already investigated whether family shareholders impact the investment-cash flow sensitivity, using various samples of countries, for example, Pindado, Requejo, and de la Torre (2011) based on Euro zone countries, Kuo and Hung (2012) and Hung and Kuo (2011) used Taiwanese firms, Andres (2011) for German listed companies, and Peruzzi (2017) for Italian small- and medium-sized enterprises (SMEs). Besides, few papers focus 
on how business groups affect the investment-cash flow sensitivity, such as Shin and Park (1999) for Korean chaebol, George, Kabir, and Qian (2011) and Lensink, van der Molen, and Gangopadhyay (2003) for Indian firms, and Hoshi, Kashyap, and Scharfstein (1991) for Japanese keiretsu groups. However, as far as we know, no previous researches have considered the effect of family-pyramidal and nonfamily-pyramidal ownership in investment-cash flow sensitivity in the literature, even more when we take as focus Brazilian corporations.

The main concern around the investment-cash flow sensitivity is whether internal funds (cash flow) should matter for investments (Ağca and Mozumdar 2017). Several researches assume the positive investment-cash flow sensitivity as an indicator of financial constraint (Fazzari, Hubbard, and Petersen 1988; Crisóstomo, López-Iturriaga, and Vallelado González 2014; Francis et al. 2012; Peruzzi 2017), while others argue that it may reflect expectations of future returns (Cleary 1999; Kaplan and Zingales 1997), or evidence agency problems related to the use of free cash flows, resulting in overinvestment (Jensen 1986; Stulz 1990). In this context, to ignore the role of cash flow on corporate investment may conduct to ambiguous interpretations of the investmentcash flow sensitivity which can be aggravated when we interact this sensitivity with ownership structure features. Notably for family firms and pyramidal ownership, the potential contradictions related to the role of the cash flow is intensified by the fact of the literature provides no consensus on whether family ownership and pyramid are beneficial or detrimental to corporate investment.

The arguments for better investment decision-making of family firms in relation to nonfamily firms are basically focused in how family shareholders may mitigate asymmetric information problems. For instance, Anderson, Mansi and Reeb (2003) and Jensen and Meckling (1976) argue that family monitoring reduces conflicts of interest 
between managers and shareholders due to the family participation in management and access to control-enhancing mechanisms to better discipline managers. In this sense, family firms could avoid high risk activities and pursue low risk investment project (Shleifer and Vishny 1986). In addition, controlling families can contribute to reduce asymmetric information problems because they may have long-standing expertise in the firm's business as well as strong commitment with its financial stability and permanence in the market (Pindado et al., 2011; Andres, 2011; Kuo \& Hung, 2012). Cucculelli and Peruzzi (2017) show that financial intermediaries need as much information as possible to mitigate asymmetric information and properly evaluate the creditworthiness for family founders. Besides, family firms may have lower financing costs (Kuo and Hung 2012; Anderson, Mansi, and Reeb 2003), because reputational concerns induce higher earning quality (Wang 2006), and their closer relationship with stakeholders may triggered softinformation based and long-term lending ties, which improves the access to credit (Cucculelli and Peruzzi, 2018), contributing for the alignment of information.

However, several papers highlight the detrimental side of family ownership when ownership is concentrated, defending its negative effect on the decision-making process (Jensen and Meckling, 1976). Family ownership may exacerbate conflicts of interest due to the potential of controlling shareholder to expropriate wealth from minority shareholders, aggravating agency problems (Anderson and Reeb 2003; Almeida and Wolfenzon 2004; Villalonga and Amit 2006). Different strategies may be used as form of expropriation, for example: managers can pursuit conservative corporate policies to beneficiate family owners (Villalonga and Amit 2006), or also can be reluctant to make merger and acquisitions - that could improve firm value - when family's stake is not sufficient to guarantee control (Caprio, Croci, and Giudice 2011), or even may use dual- 
class shares and pyramids to disentangle voting control and economic ownership (divergence between control rights and cash flow rights) (Claessens et al. 2002).

The expropriation of minority shareholders wealth in a pyramidal chain is called tunneling and is probably related to poor investor protection (La Porta et al. 2000; Almeida and Wolfenzon 2006). The expropriation tends to occur from firms in which the controlling shareholder has low cash flow rights toward others with larger amount of cash flow rights (Bertrand, Mehta, and Mullainathan 2002). In this sense, business groups seem to be more interesting for family shareholders than stand-alone firms since they can pursuit private benefits of control and share any corporate risk with other firms (and nonfamily shareholders) belonged to pyramid. At the perspective of tunneling, pyramidal ownership has a detrimental side on corporate investment, increasing the potential of family shareholders for overinvestment decisions and intensifying agency problems.

Nevertheless, other researches provide evidence that pyramidal ownership may not only emerge for keeping large shareholders' control but also to mitigate financial constraint at country and firm levels (Masulis, Pham, and Zein 2011) due to an "internal capital market" (Buchuk et al. 2014; Almeida and Wolfenzon 2006; Almeida et al. 2011; Shin and Park 1999). Johnson et al. (2000) denominate as propping the transference of resources among firms in the business groups that helps to overcome market frictions and creates financial advantages. From propping view, firms with limited access to external resources to fund growth opportunities can receive financial support from other financially healthy companies that belonged to the pyramid (Buchuk et al. 2014; Gopalan, Nanda, and Seru 2014). Thus, at the propping perspective, pyramidal ownership seems to contribute to alleviate financial constraint and enhance corporate investment.

What the literature commonly shows is that family control and pyramidal ownership can contribute both to intensify agency problems and mitigate asymmetric information. 
Then, understanding their effect on investment-cash flow sensitivity may be a hard task if we regard that the role of cash flow in investment decisions is an open question, as aforementioned. Most of previous evidences about the effect of family ownership in the investment-cash flow sensitivity do not give enough attention whether cash flow reflects agency problems, financial constraint, or future earnings. Two exceptions are found in Andres (2011) which discriminate firms according to their size and dividend payout as proxy for financial constraint, and Kuo and Hung (2012) which based on Tobin's $q$ to capture agency problems of free cash flow. Similar criticism can also be appointed when previous studies focus on the effect of pyramidal ownership in investment-cash flow sensitivity.

The main goal of this paper is to provide a better understanding of the relation between family control, pyramid and investment-cash flow sensitivity taking into account the liquidity constraint in investment decisions. We differentiate firms according to two financial constraint indexes widely used in the literature: $\mathrm{KZ}$ index and $\mathrm{WW}$ index. Yet, we conduct several robustness checks with other criteria, such as size and dividend payout.

Our analysis proceeds in three stages. First, we focus on the possible effect of family control on investment-cash flow sensitivity for financially constrained and unconstrained firms. We examine whether the relation between family control and corporate investment is affected by the active involvement of family members on the board of directors and in management as CEO. Second, we explore how pyramidal ownership may interfere on investment-cash flow sensitivity of constrained and unconstrained firms. Finally, we control for the effect of pyramid in corporate investment to be driven by the potential of family shareholders extract private benefits of control. In this sense, we consider the 
divergence between voting rights and cash flow rights in pyramidal- and nonpyramidalfamily controlled corporations.

To conduct our tests, we rely on a sample of 399 Brazilian public traded firms over the period of 1997-2007. An important motivation to study Brazilian firms is the peculiar and rich scenario of this emerging economy represents. One of the reasons to focus on Brazilian economy is that most of firms face very high external financing costs when compared with their counterparts in other emerging market countries (Almeida and Eid Jr, 2014). The Brazilian Development Bank (BNDES), a state-owned development bank, has historically been the main supplier of long-term funds. As BNDES subsidized loans are mostly destined to large firms, the great majority of Brazilian firms should rely on their own resources to fund investment, complementing the residual financing requirements with expensive short-term. A second reason is that a great portion of Brazilian public traded firms is controlled by a family. In fact, our sample provides evidence that more than $43 \%$ of firms have a family as controlling shareholder. A third reason is related to the issuance of non-voting shares, which are widespread in Brazil, implying deviation from the one share-one vote rule, and Brazilian firms are mostly structured by pyramidal arrangement. Therefore, the combination of high interest rate for long-term investments, family control and pyramidal ownership of Brazilian firms offers a rich environment to investigate corporate investments.

Our study provides relevant implications that contributes to literature. First, we show that when firms face financial constraint, family control does not affect the sensitivity of investment to cash flow. This finding keeps even when family members are actively involved in board and management's activities. Second, family control seems to be an important feature to explain the relation between investment spending and cash flow of unconstrained firms. In such group, family control reduces investment-cash flow 
sensitivity, but it turns to increase when family members participate of the board. Third, our results provide evidence that pyramidal ownership in Brazil seems to be driven by the internal capital market idea. Finally, few papers have focused on Brazilian scenario to analyze investment decisions and financial constraint (Kalatzis and Azzoni 2009; Kalatzis, Azzoni, and Achcar 2008), even less have considered the influence of ownership structure on investment-cash flow sensitivity (Crisóstomo, López-Iturriaga, and Vallelado González 2014). In sum, our study brings new light on how family firms and pyramidal ownership influence investment-cash flow sensitivity when firms of an emerging country as Brazil face financial constraint and when they do not.

2. The investment-cash flow sensitivity

\subsection{The role of cash flow}

Fazzari et al. (FHP) (1988) associate investment-cash flow sensitivity to financial constraint since the low-dividend group of a sample of US manufacturing firms showed to be more dependent of internal resources to fund capital expenditure. Investigating the same sample, Kaplan and Zingales (KZ) (1997) reclassified FHP's (1988) low-dividend firms according to operating performance. The results showed that $85 \%$ of them had increased the investment rates by relying on cash and credit lines, suggesting that higher investment-cash flow sensitivity might be indicating higher future earnings rather than financial constraint. Cleary (1999) corroborates KZ (1997) while Gomes (2001) points to the lack of theoretical foundations for a positive linkage between investment and cash flow. However, using different firm-level proxies for asymmetric information (such as size, age, ownership structure, capital intensity, commercial papers, and bond ratings), several studies have confirmed that investment is related to cash flow (Hoshi, Kashyap, and Scharfstein 1991; Bond and Meghir 1994; Kadapakkam, Kumar, and Riddick 1998; 
Schaller 1993; Gilchrist and Himmelberg 1995; Kalatzis and Azzoni 2009; Ağca and Mozumdar 2017).

The controversy around the investment-cash flow sensitivity has motivated some studies to focus on the definition of financial constraint as well as on sample characteristics. Cleary Povel, and Raith (2007) argue that while KZ (1997) and Cleary (1999) split their sample according to the availability of liquidity, FHP (1988) use a sample of financially wealthy firms and a measure of market imperfection as proxy for financial constraint. Cleary, Povel, and Raith (2007) also document a positive relationship between investment-cash flow sensitivity and the level of asymmetric information. However, when they use the level of internal funds as a proxy for financial constraint, they identify a U-shaped relationship between firm's investment and cash flow. Guariglia (2008) find similar results for a sample of UK firms by using size and age as proxies for asymmetric information and coverage ratio and cash flow to measure internal funds.

Investment sensitivity to cash flow is also observed in firms classified as financially unconstrained. For instance, Kadapakkam et al. (1998) find evidence that large corporations' investment in six OECD countries is more sensitive to cash flow. As large firms are less vulnerable to asymmetric informational problems (they usually have good reputation and more collateral), the higher sensitivity is associated with agency conflicts: large corporations are generally widely-held and therefore their management are less subject to monitoring, leaving large scope for spending free cash flows in valuedecreasing investments. As Jensen (1986) emphasizes, the availability of free cash flows may prompt management to overinvest in projects from which they extract high private benefits of control. Pawlina and Renneboog (2005), Degryse and De Jong (2006) and 
Pindado and De La Torre (2009) follow Jensen (1986) to interpret the positive relationship between investment and cash flow in firms with low growth opportunities.

Due to ambiguous interpretation around investment-cash flow sensitivity, financial constraint indexes have been suggested to capture firms' liquidity constraint. As proposed by KZ (1997), a measure of financial constraint should consider internal funds level, besides of regarding on qualitative information to identify the presence of financial constraint. Using subjective and objective criteria to rank the low-dividend firms of FHP (1988)'s sample, KZ (1997) estimate an ordered logit model as a function of five variables: cash flow, dividend payout, cash balances, leverage and Tobin's $q$. The estimated coefficients of this regression allowed Lamont, Polk, and Saá-Requejo (2001) to construct a "synthetic financial constraint index", named as $\mathrm{KZ}$ index. Another financial constraint index, proposed by Whited and Wu (2006), exploits an Euler investment equation approach to create the WW index. The level of financial constraint is measured as function of six factors: cash flow, dividend dummy, firms' size, industry sales growth, sales growth, and leverage. As firms' size is closely related to financial constraint, Hadlock and Pierce (2010) suggest that WW index may better capture liquidity constraint than $\mathrm{KZ}$ index.

\subsection{The family control effect}

Kuo and Hung (2012) and Hung and Kuo (2011) provide evidence that the investmentcash flow sensitivity for family firms is higher than for nonfamily firms and the difference tends to decline when family firms have higher growth opportunities. These results support the view that high-growth family firms are less prone to asymmetric information problems and financial constraints. They argue that outside investors perceive the controlling families as having superior knowledge about the firms' business and are committed to the firms' permanence in the market. Kuo and Hung (2012) find that 
investment in low-growth family firms is more sensitive to cash flow in those whose ultimate owners have control rights far exceeding their cash-flow rights. Pindado et al. (2011) reach a similar conclusion that family firms have lower investment-cash flow sensitivity, and that this potential benefit disappears when voting rights exceed cash flow rights.

Analyzing Italian medium- and small-sized enterprises (SME), Peruzzi (2017) assumes investment-cash flow sensitivity as a proxy for financial constraint and find higher sensitivity for family firms. This finding is interpreted as a sign that ownership concentration and family management increases firm's financial constraint. Gugler (2003) also show that family firms are more subject to financial constraint. In the same line, Andres (2011) consider firm size and dividend payout as criteria to control for the role of cash flow in investment decisions. The results show higher investment-cash flow sensitivity for family firms, which is mainly observed in those considered as financially unconstrained ones. He interprets these findings as an evidence that family firms are more stable that nonfamily counterparts with similar size and dividend payout.

Taking into account the firms' financial situation, we investigate whether the effect of family control, if any, on investment decisions may be determined by other features, as management and board activities. We propose that if the ultimate owner is a member of the board or CEO, investment-cash flow sensitivity of financially constrained firms controlled by families is lower than those nonfamily-controlled due to the beneficial side of family ownership to mitigate asymmetric information. At the detrimental side of family ownership, we should expect higher investment-cash flow sensitivity in familyfinancially constrained firms, because the presence of family members on the board and in management increases interest conflicts. Besides, if the ultimate owner is a member of the board or CEO, investment-cash flow sensitivity of financially unconstrained firms 
controlled by families can be higher than those nonfamily-controlled due to agency problems.

\subsection{The pyramid effect}

Bianco and Casavola (1999) argue that pyramidal firms, notably those with low availability of internal funds and tight financial constraint, tend to invest more because they may benefit from internal capital market among firms that belonged to business group. Similar evidence is found by Shin and Park (1999) when they investigate investment-cash flow sensitivity of Korean chaebols firms, a kind of pyramidal ownership. In their study, the investment of chaebols firms is no dependent of internal funds in comparison to non-chaebols firms, whose investments are significantly affected by cash flow. Lensink, Molen and Gangopadhyay (2003) also find that pyramidal firms are less dependent of cash flows to finance investment than stand-alone firms, suggesting that the former faces less financial constraint. Conversely, George, Kabir and Qian (2011) do not identify significant differences in investment-cash flow sensitivity between Indian pyramidal and independent firms.

When Japanese pyramidal (keiretsu) firms have closer relationship to a bank, Hoshi, Kashyap, and Scharfstein (1991) show that the investment are less sensitive to internal funds due to mitigation of asymmetric information. Kato, Loewenstein, and Tsay (2002) also find higher investment-cash flow sensitivity for stand-alone firms in comparison to keiretsu groups. With a sample of Chinese firms, He et al. (2013) evidence the importance of business group to alleviate financial constraint. They argue that pyramidal ownership works as an internal capital markets and the negative effect on investment-cash flow sensitivity is more likely to be observed in state-owned firms.

To the best of our knowledge, we do find evidences related to the effect of pyramidal ownership on investment-cash flow sensitivity in Brazilian corporations. In this sense, 
considering the propping (internal capital markets) and tunneling (expropriation) as possible results of pyramidal ownership, we expect different effects according to the presence of financial constraints. Investment-cash flow sensitivity could be lower for constrained firms when they are owned through pyramidal schemes because they benefit from the transfer of funds among the affiliated firms. Or yet, for both financially constrained and unconstrained firms, investment-cash flow sensitivity could be higher when they are owned through pyramidal schemes because tunneling propitiates expropriation of free cash flow.

\section{Data and Model}

We use three different sources to construct our dataset. Ownership data were manually collected for every company and year over the period from 1997 to 2007 from Informações Anuais (IAN, Annual Informative Report), a report which publicly traded companies had to file with Comissão de Valores Imobiliários (CVM), Brazil's capital market regulator. IAN provides data such as types and numbers of shares held by firms' largest shareholders, composition of the management team and the board of directors, and whether the firm belongs to business groups. Besides ownership data, we use financial and accounting data, which are provided by Economatica. Data about firms' listing segment is drawn from the website of the Brazilian Stock Exchange (BM\&FBovespa). We exclude financial firms and firms for which financial or ownership data are inconsistent or missing. The resulting sample is an unbalanced panel of 399 public companies over the period 1997-2007 (2,329 firm-year observations).

\subsection{Financial Constraint Indexes}


As commented before, we rely on two indexes to distinguish firms that are likely to face financial constraint from those that are not: the KZ index and the WW index. The Kaplan-Zingales (KZ) index is calculated according to equation (1):

$$
\text { KZIndex }_{i t}=-\left(1.0019 * \frac{C F_{i t}}{K_{i, t-1}}\right)+\left(0.2826 * Q_{i t}\right)+\left(3.1391 * \frac{\text { Debt }_{i t}}{\text { TotCap }_{i t}}\right)-\left(39.3678 * \frac{\text { Dividend }_{i t}}{K_{i, t-1}}\right)-\left(1.3147 * \frac{\text { Cash }_{i t}}{K_{i, t-1}}\right)
$$

where $K$ denotes capital stock, measured as the value of property plant and equipment net of depreciation; $C F$ is the sum of net income, depreciation and amortization, normalized by capital stock in the beginning of the period; $Q$ is the proxy for Tobin's $q$, measured as the sum of the market value and total debt, divided by total assets; Debt represents the sum of long-term and short-term debt, normalized by capital stock in the beginning of the period; TotCap is the sum of total debt and stockholder's equity; Dividend is the dividend payout, measured as the dividends paid by preferred stocks and common stock multiplied by the corresponding amount of shares; and Cash is the sum of cash and short-term investments.

Put forward by Whited and Wu (2006), the WW index draws on the investment Euler equation and measures the degree of financial constraint as a function of the following variables:

WWIndex $_{i t}=-\left(0.091 \cdot \frac{\text { Cash Flow }_{i t}}{T A_{i, t-1}}\right)-\left(0.062 \cdot\right.$ DIVPOS $\left._{i t}\right)+\left(0.021 \cdot \frac{\text { Debt }_{i t}}{T A_{i, t-1}}\right)-0.044 \cdot \ln \left(T A_{i t}\right)+0.102 \cdot I S G_{i t}-0.035 \cdot S G_{i t}$

where TA is total assets; DIVPOS is a dummy variable that takes value 1 if the firm pays dividends, and zero otherwise; $I S G$ is the industry sales growth, and $S G$ is the firm real sales growth.

As economic conditions can affect the magnitude of financial constraint, we compute the $\mathrm{KZ}$ and the WW indexes for every firm and year. Higher values for both indexes indicate higher likelihood of financial constraint. We divide the KZ and WW indexes by quintiles and firms in the first and second quintiles are classified as financially 
unconstrained, while those in the fourth and fifth quintiles are classified as financially constrained.

\subsection{Econometric Models}

We employ a dynamic and non-linear version of the accelerator model, in which the dependent variable $\left(I_{i t}\right)$ is the investment rate, measured as $\left(K_{i t}-K_{i, t-1}\right) / K_{i, t-1}$ where $K$ is capital stock. The following investment model is applied to conduct our tests:

$$
\begin{aligned}
I_{i t}=\beta_{0}+\gamma_{1}\left(I_{i, t-1}\right) & +\gamma_{2}\left(I_{i, t-1}\right)^{2}+\beta_{1} C F_{i t}+\beta_{2} F D_{i t}+\beta_{3}\left(C F_{i t} * F D_{i t}\right)+\beta_{4} \text { Board }_{i t}+\beta_{5}\left(C F_{i t} * \operatorname{Board}_{i t}\right) \\
+ & \beta_{6}\left(F D_{i t} * \operatorname{Board}_{i t}\right)+\beta_{7}\left(C F_{i t} * F D_{i t} * \operatorname{Board}_{i t}\right)+\beta_{8} C E O_{i t}+\beta_{9}\left(C F_{i t} * C E O_{i t}\right) \\
+ & \beta_{10}\left(F D_{i t} * C E O_{i t}\right)+\beta_{11}\left(C F_{i t} * F D_{i t} * C E O_{i t}\right)+\varphi X_{i t}+\alpha_{i}+v_{t}+\varepsilon_{i t}
\end{aligned}
$$

where $\alpha_{i}$ is the firm-specific effect; $v_{t}$ is the time-specific effect; and $\varepsilon_{i t}$ is the error term. The family dummy $(F D)$ variable assumes value 1 if large shareholder holds the control of firm and represents a family, and 0 otherwise. The relationship between cash flow, family control and his presence on the board (or as $C E O$ ) is represented by the interaction term $C F^{*} F D^{*}$ Board (and $C F^{*} F D^{*} C E O$ when the largest shareholder is the CEO).

We also include other firm-level characteristics that are usually used in investment models, represented by $X_{i t}$ in model (3). Financial variables of this set include sales growth $(S G)$ to control for growth opportunities, debt and firms' size. We control our results by the level of leverage (the debt variable), measured by total debt as ratio of capital stock, due to two reasons. The first is related to debt tax benefits and the second is based on agency theory that defends leverage as a governance mechanism to better discipline managers and to reduce asymmetric information. ${ }^{1}$ The inclusion of Size variable is to control investment decisions by firm's size, because smaller and younger firms are more

\footnotetext{
${ }^{1}$ See Jensen (1986).
} 
likely to underinvest since they are at disadvantage to get access to external finance due to short collateral and track records.

The set $X_{i t}$ has also the Divergence and $C G$ variables which the first captures the excess of voting rights of the largest ultimate shareholder, measured by the difference between voting rights and cash flow rights, while the $C G$ variable is a proxy for good corporate governance. The main reason to include Divergence is to control the investment behavior considering the tendency of family members to pursuit private benefits of control and expropriate the wealth of minority shareholders. Finally, the last variable is based on the three listing segments created by the Brazilian stock exchange (Level 1, Level 2, and Novo Mercado), all of which require stricter governance standards than that legally mandatory. ${ }^{2}$ Listing on these segments is voluntary and regulated by private contracting. We construct the $C G$ variable as taking value 1 if the firm is listed in one of these three segments and 0 otherwise. Regardless the premium listing segment, firms that voluntarily listed in Level 1, Level 2 or Novo Mercado must provide better disclosure in relation to traditional segment, mitigating information asymmetry and improving transparency. As consequence, it is expected lower financing costs for firms with better governance statements, which should contribute to intensify corporate investments.

Next, to investigate the effect of pyramidal arrangements in investment-cash flow sensitivity of financially constrained and unconstrained firms, we interact the cash flow variable $(C F)$ with the $P D$ variable, which takes value 1 if the firm belongs to a pyramidal scheme and 0 otherwise. Our second investment model is:

$$
I_{i t}=\beta_{0}+\gamma_{1}\left(I_{i, t-1}\right)+\gamma_{2}\left(I_{i, t-1}\right)^{2}+\beta_{1} C F_{i t}+\beta_{2} P D+\beta_{3}\left(C F_{i t} * P D_{i t}\right)+\varphi X_{i t}+\alpha_{i}+v_{t}+\varepsilon_{i t}
$$

\footnotetext{
${ }^{2}$ Level 1 requires better disclosure and information about insiders' ownership, among other features. The major requirements for companies on Level 2 are that they have to comply Level 1 requirements, besides of voting rights to preferred shareholders, equal treatment to minority common shareholders in case of control transfers, and independent directors composing at least $20 \%$ of the board. Firms listed on the Novo Mercado, the premium corporate governance segment, have to consent with Level 2 requirements and the rule of "one share-one vote."
} 
Then, to investigate the effect of pyramidal arrangements in family firms, we first include two interaction variables in equation (4): $P D^{*} F D$ that assumes value 1 if the firm belongs to a pyramidal scheme and is controlled by a family, and 0 otherwise; and the $P D *(1-F D)$ variable that captures the effect of pyramidal ownership in nonfamily firms. We also interact those two interaction variables with cash flow to capture their effects in investment-cash flow sensitivity.

We use the two-step system GMM estimator (GMM-sys) of Blundell and Bond (1998) with Windmeijer (2005) robust correction to estimate the investment models. The validity of the instruments is checked by the Arellano-Bond test, which tests the second-order serial correlation $\left(m_{2}\right)$, and the Sargan test for over-identification to verify the validity of the instruments. Some studies, such as Cho (1998), Pindado and de la Torre (2004), Pindado et al. (2011), and Wintoki et al. (2012), defend that ownership structure should be treated as endogenous rather than exogenous. Ownership structure affects investment decisions and in consequence, also influences firm value; however, because corporate investments impact firm value, then they also modify ownership structure (Cho, 1998). In this sense, we treat ownership variables, i.e, family control, pyramid, CEO, Board, divergence, as endogenous variables and we use first lagged values as instrument.

\section{Results}

Table 1 reports summary statistics and mean difference tests between the groups of financially constrained and unconstrained firms. For brevity, we refer to the groups of firms classified according to the KZ index (WW index) as financially constrained and unconstrained such as $K Z_{F C}$ and $K Z_{F U C}\left(W W_{F C}\right.$ and $\left.W W_{F U C}\right)$, respectively. 
Panel A of table 1 presents the summary statistics for financial variables. On average, the investment rate for $K Z_{F U C}$ and $W W_{F U C}$ represents $3 \%$ and $4 \%$, respectively, while, for constrained firms, the average investment rate is negative $(-2 \%)$ for $K Z_{F C}$ and it is zero for $W W_{F C}$. For both indexes, average cash flows and profitability measures (ROA, ROE) are positive for financially unconstrained firms and negative for firms considered as financially constrained, except for cash flow of $\mathrm{WW}_{\mathrm{FC}}$ firms. Firms classified by both indexes as financially unconstrained are larger, less leveraged, and have higher sales growth than those classified as financially constrained. The greater availability of tangible assets of unconstrained firms may indicate their higher capability to provide collateral to long-term borrowing (Almeida, Campello, and Weisbach 2004; Gilchrist and Himmelberg 1995). It is worth noting that the average size of $W W_{F U C}$ is more than fifteen times larger than that for $W W_{F C}$, while this proportion for $K Z_{F U C}$ and $K Z_{F C}$ is just 1.27.

Summary statistics for governance and ownership variables are shown in Panel B of table 1. For all these variables, the WW index entails significant mean difference tests, indicating that it sharply discriminates the groups of financially constrained and unconstrained firms. Regardless the index, the percentage of family firms is larger in financially constrained firms, although the difference is higher for firms classified by the WW index: families control nearly $57 \%$ of the $\mathrm{WW}_{\mathrm{FC}}$ and only $27 \%$ of the $\mathrm{WW}_{\mathrm{FUC}}$. The largest shareholder is a director and a CEO in $71 \%$ and $52 \%$ of $\mathrm{WW}_{\mathrm{FC}}$, respectively. Using any of the two indexes, the fraction of firms listed in the premium governance segments is lower for those classified as financially constrained, suggesting that it may be costlier for them to adopt better governance practices. Our summary statistics also show higher concentration of pyramidal ownership in $\mathrm{WW}_{\mathrm{FUC}}$ group than in WWFC, but there is no statistical difference for firms grouped by $\mathrm{KZ}$ index. 


\subsection{The effect of family firms in investment-cash flow sensitivity}

Table 2 presents the regression results for the effect of board, CEO and family control in investment-cash flow sensitivity of financially constrained firms grouped by KZ and WW index. Except in column (1b) of Table 2, the relation between cash flow and investment rate is statistically significant in all specifications. As current profitability is negative for $K Z_{F C}$ and $W W_{F C}$ firms, ${ }^{3}$ the positive investment-cash flow sensitivity is in line with Fazzari, Hubbard, and Petersen (1988), revealing financial constraint rather than future profitability and overinvestment, as pointed by Kaplan and Zingales (1997) and Jensen (1986).

[Insert Table 2 about here]

Columns (2a) and (2b) of Table 2 report that the coefficients of $C F^{*} F D$ are insignificant at conventional levels. Coherently with Andres (2011), our results imply that family control may not directly influence investment decisions of financially constrained firms. ${ }^{4}$ Columns (3a) and (3b) of Table 2 show that the coefficients of $C F^{*}$ Board are negative in both columns but significant only for $K Z_{F C}$ firms. The findings evidence that the presence of the large shareholder on the board may reduce investmentcash flow sensitivity, mitigating asymmetric informational problems that could intensify the financial constraint situation. Besides, this effect seems not to be influenced by whether the firm is controlled by a family since the coefficient of $C F^{*} B o a r d * F D$ in columns (4a) and (4b) of Table 2 is no significant at conventional levels. Similar results are found for the effect of CEO in investment decisions. For columns (5a) and (5b), the coefficient of $C F^{*} C E O$ is negative and significant for $K Z_{F C}$ firms, but insignificant for

\footnotetext{
${ }^{3}$ See table 1.

${ }^{4}$ Andres (2011) find that the cash flow coefficient for family firms is not statistically different from zero for small firms and low-payout firms (both groups of financially unconstrained firms).
} 
$W W_{F C}$ firms, while columns (6a) and (6b) show that the interaction term $C F^{*} C E O^{*} F D$ is insignificant at conventional levels for both groups.

In sum, the insignificant effect of $C F^{*} B o a r d * F D$ and $C F^{*} C E O * F D$ show that there is no association between the negative effects of Board and CEO in investment-cash flow sensitivity and family control for $\mathrm{KZ}_{\mathrm{FC}}$ firms. In this sense, regardless whether the firm is family- or nonfamily-controlled, the active involvement of large shareholder in the board or management helps to alleviate the use of internal resources in corporate investments, probably because it mitigates conflicts of interest when firms face financial constraint.

Table 3 presents the results for firms classified as financially unconstrained by $\mathrm{KZ}$ and WW indexes.

[Insert Table 3 about here]

Columns (1a) and (1b) show that the effect of cash flow is positive and significant for financially unconstrained firms. The positive investment-cash flow sensitivity can be attributed to agency problems, as discussed by Jensen (1986), or future investment opportunities, as proposed by Kaplan and Zingales (1997). Firms classified as financially unconstrained ones are larger and present high cash flow ratios and stable financial conditions. ${ }^{5}$ Such features might alleviate agency problems related to the use of free cash flow in unprofitable projects (Jensen 1986), suggesting that the positive investment-cash flow sensitivity is more likely to result of agency conflicts.

Columns (2a) and (2b) of Table 3 show that $C F^{*} F D$ has a negative effect on investment decisions, however this coefficient is only significant for firms grouped by $\mathrm{KZ}$ index. Opposed to constrained firms, the active involvement of ultimate owners in the board seems to have no direct effect on investment rate since the coefficient of $C F^{*}$ Board is insignificant at conventional levels, as presented in columns (3a) and (3b).

\footnotetext{
${ }^{5}$ See table 1.
} 
The effect of $C F^{*}$ Board ${ }^{*} F D$ is positive and significant for both groups of firms, indicating that family owners increase investment-cash flow sensitivity of unconstrained firms when they are members of the board. Columns (5a) and (5b) of Table 3 report the effect of CEO in investment rate, showing that the coefficient of $C F^{*} C E O$ is insignificant for unconstrained firms of both indexes. However, as shown in columns (6a) and (6b), the interaction term with family control $\left(C F^{*} C E O^{*} F D\right)$ is positive and only significant for WW unconstrained firms (6b).

In sum, our findings show that investment-cash flow sensitivity of unconstrained firms is increased when family owners are members of the board or assume top management positions. Peruzzi (2017) find similar results about the effect of family management in the dependence of investment spending to internal resources, considering their total sample. Our results go a step forward and show that the positive relation between family management (board and CEO) and investment-cash flow sensitivity is potentially derived from agency problems rather than financial constraint.

\subsection{The effect of pyramidal ownership in investment-cash flow sensitivity}

To test how pyramidal ownership is related to investment-cash flow sensitivity of constrained and unconstrained firms, we estimate the investment model described in eq. (4). The results are presented in Table 4.

\section{[Insert Table 4 about here]}

The interaction coefficient between cash flow and pyramid, represented as $C F^{*} P D$, is negative and significant for constrained firms grouped by $\mathrm{KZ}$ index, but it is insignificant at conventional levels for $W W_{F C}$ firms (see column 4a). Similar results are found in columns (1b) and (4b) for unconstrained firms, although the coefficient of $C F^{*} P D$ is only significant in column (4b) for $W W_{F U C}$ firms. Our findings show that pyramid reduces 
investment-cash flow sensitivity, or even makes investment spending no dependent of internal resources.

To better investigate the pyramid effect, we disentangle the effect of family control from the pyramidal ownership. The intention is to understand whether family ownership interfere on the association between pyramid and investment-cash flow sensitivity. Then, we consider the relation of family control, pyramid and high and low levels of divergence between voting rights and cash flow rights. As high divergence induces high potential for expropriate minority shareholders' wealthy (Claessens et al. 2002), intensifying agency problems and asymmetric information, we should expect higher investment-cash flow sensitivity for family-pyramidal firm. However, this is not what we observe in our findings.

Our results in columns (2a) and (5a) show that pyramidal-family controlled firms are not sensitive to cash flow for financially constrained groups. Even when we distinguish between the effects of high and low divergence between voting rights and cash flow rights, the results remain insignificant at conventional levels (see columns (3a) and (6a)). Considering $K Z_{F C}$ firms, our results evidence that family control neutralizes the negative effect of pyramid on investment-cash flow sensitivity, while this effect seems to be an exclusive feature of firms whose large shareholders are not the family-controlling shareholder of the business group. ${ }^{6}$

Considering the groups of unconstrained firms, the coefficients of $C F^{*} P D^{*} F D$ and $C F^{*} P D^{*}(1-F D)$ in columns $(2 \mathrm{~b})$ and $(5 \mathrm{~b})$ are negative and significant, except for the last variable which is insignificant for $K Z_{F U C}$ firms. Additionally, the coefficients of $C F^{*} P D^{*} F D^{*} H i g h \_D i v$ and $C F^{*} P D^{*} F D^{*} L o w \_D i v$ are negative and significant in columns (3b) and (6b), except for the last variable in column (3b) which is insignificant.

\footnotetext{
${ }^{6}$ Note that the $C F^{*} P D^{*}(1-F D)$ variable is negative and significant.
} 
The results evidence that the significant negative effect of $C F^{*} P D^{*} F D$ is observed in unconstrained firms with both high and low divergence. In sum, table 4 shows that the results of both constrained and unconstrained firms are potentially driven by the effect of pyramid on investment-cash flow sensitivity rather than family control and divergence. In other words, for pyramidal ownership, the findings seem to be more in line to the internal capital market idea.

\section{Robustness Check}

We subject our findings to different robustness checks. First, the main reason to adopt the top two quintiles and the bottom two quintiles to discriminate the sample is to include as many observations as possible in our estimates, excluding intermediary firms that could not effectively be subject to financial constraint. For robustness, we modify the threshold of KZ index and WW index, and we re-estimate all results of Table 2-4 using median and terciles values as cut-off point. With terciles, the results are quite similar as those for quintiles, although for median values, some variables become insignificant, as the case of $C F^{*} F D$ in columns (4b) and (6b) for Table 3 and $C F^{*} P D^{*} F D$ in column (5b), which remain negative but not significant at conventional levels. This problem may be occurring due to failures in distinct constrained and unconstrained firms.

Second, we opt to apply KZ index and WW index as financial constraint criteria because they are indexes created and consolidated by the literature, with the main goal to rank firms according to the degree of financial constraint. However, we re-estimate our results with firm size and dividend payout since they are two criteria widely used in literature. Thereby, large firms in the top two quintiles of total assets are named as financially unconstrained and small firms in the bottom two quintiles of total assets assign to financially constrained group. Using firm size, our findings are similar to those showed 
in Table 2-4 for firms grouped according to WW index. The only two exceptions are the insignificance of $C F^{*} F D$ and $C F^{*} F D^{*}$ Board and the significance of $C F^{*}$ Board for large firms. These results suggest that large shareholders as member of the board may reduce investment-cash flow sensitivity in large firms, regardless whether this shareholder represents a family. For dividend payout criterion, we consider firms as financially constrained if they do not pay dividends. For firms that pay any amount of dividend, we rank them to designate the top two terciles of non-null payout as financially unconstrained ones. ${ }^{7}$ In the last group, we find quite similar results to $\mathrm{KZ}$ and $\mathrm{WW}$ indexes for unconstrained group, reinforcing that $C F^{*} F D, C F^{*}$ Board and $C F^{*} P D^{*} F D$ have a negative and significant effect on investment decisions while $C F^{*}$ Board ${ }^{*} F D$ is positive and significant.

Third, studies as Pindado et al (2011), Kuo and Hung (2012) have pointed out that sometimes the effect of controlling family may be reflecting the effect of other types of blockholders rather than be a specific family characteristic. Besides, Attig, Guedhami and Mishra (2008) show that multiple large shareholders may act as an internal governance proxy, mitigating agency and asymmetric information problems. In this sense, we evaluate two tests to investigate whether our results are affected by other types of blockholders. In our first approach we include in investment models some binary variables (and their interaction with cash flow) related to different types of controlling shareholder, such as: firms controlled by State, and foreign control. For the second, we follow Pindado et al (2011) and define blockholding as a nonfamily ultimate owner who has more than 20 percent of firm's stake. We create a miscellaneous dummy variable (Misc) that takes value 1 if the firm has more than one blockholder, and 0 otherwise. The Misc variable is interacted with cash flow and included as explanatory variable in

\footnotetext{
${ }^{7}$ We do not use the first tercile because it contains firms that pay lower dividends in relation to other payout firms.
} 
empirical models to investigate its impact in investment-cash flow sensitivity. The estimation results of the two approaches show that our previous results are not affected by another blockholder or other types of controlling shareholder.

Fourth, to assure that endogeneity problems are not affecting our System-GMM regression results about the effect of family control on investment, we follow Peruzzi (2017) and employ the propensity score matching approach (PSM). To identify the matched sample, we estimate a logit regression (of the PSM technique) in which the likelihood of being controlled by a family is explained by the divergence between voting rights and cash flow rights, the active involvement of the large shareholder in the board and in management, firm size, the standard deviation of firm's earnings, cash holdings, ROA, sales growth and year dummies. ${ }^{8}$ The matched firms consists of family and nonfamily firms sharing similar features of family ownership. To conduct our robustness check, we interact the matched firms with cash flow and other interaction variables. We re-estimate our models with such variables and the estimation results confirms our previous results. ${ }^{9}$

\subsection{A discussion about the impact of financial constraint indexes in estimation results}

Although we have conducted several robustness checks, we observe that the statistical significance of some interest variables may differ according to financial constraint index employed. For instance, $K Z_{F C}$ displays more significant results in relation to $W W_{F C}$. However, we observe that the results of the last group are similar to those obtained using firm size as criterion. We interpret this as an evidence from the weight that the WW index places on firm size. Hadlock and Pierce (2010) prefer the WW index to the KZ index

\footnotetext{
${ }^{8}$ Matched firms are select without replacement within the distance (caliper) of 0.001 .

${ }^{9}$ The results of all robustness checks commented above are provided at the supplementary material.
} 
because size is a strong sign of financial constraint. ${ }^{10}$ Firm size, measured here by the logarithm of total assets, is significantly correlated with financial and governance variables, which directly influence the likelihood of financial constraint. Actually, total assets are strongly correlated with the WW index $(\rho=0.84$, significant at $0.1 \%)$, indicating that this index may be operating as a proxy for firm's size. ${ }^{11}$

Indeed, as observed before in Table 1 , the $W W_{F U C}$ firms are, on average, more than fifteen times larger than the constrained ones $\left(W W_{F C}\right)$ while $K Z_{F U C}$ has almost the same size of $K Z_{F C}$ firms. Taking into account both indexes, the firm's size of $K Z_{F C}$ group is around seven times greater than those of $W W_{F C}$. Likewise, the $W W_{F U C}$ are almost twice times larger than $K Z_{F U C}$ firms. No wonder that the estimation results are different. ${ }^{12} \mathrm{We}$ can thus infer that the impact of family control and pyramid on investment decisions of Brazilian public companies may vary according to the firm's size and the presence of financial constraint.

\section{Conclusion}

This paper focuses on financial constraint to investigate the effects of family control and pyramidal ownership on investment decisions by using data from Brazilian public companies over the period 1997-2007. Two financial constraint indexes are employed to classify firms a priori: the KZ index and the WW index. Regarding ownership features,

\footnotetext{
${ }^{10}$ Devereux and Schiantarelli (1990), Gilchrist and Himmelberg (1995), and Almeida and Campello (2004) use firm size to distinguish financially constrained (small) from unconstrained (large) firms. For Schiantarelli (1996), "size is highly correlated with the fundamental factors that determine the probability of being constrained," arguing that small firms usually are young and have short collateral and track records, being therefore at disadvantage to get access to external finance.

${ }^{11}$ The correlation between KZ index and firms' size is negatively significant at $1 \%(\rho=-0.20)$.

${ }^{12}$ Sorting the four groups according to their total asset average, $W W_{F U C}>K Z_{F U C}>K Z_{F C}>W W_{F C}$.
} 
the last index seems to provide a more clear-cut discrimination between those two groups of firms, probably because of the high correlation of WW index with the firm's size.

For financially constrained firms, we find no significant difference between how investment decisions are sensitivity to internal resources of family- and nonfamilycontrolled firms. This is also observed when we examine how the investment-cash flow sensitivity is influenced by the active involvement of family members in the board of directors or as CEO. However, for unconstrained firms, we find that family control decreases investment-cash flow sensitivity but turn to be positive when the controlling family is a member of the board. We interpret our results as an evidence that to be controlled by a family in Brazilian economy is not a harmful feature for investment decisions. Family control becomes threatening for investors when firms are not in financial constraint situation and family members actively participates in the management. With this ownership configuration, the detrimental side of family control (agency problems and private benefits of control) tends to stand out over its positive effect of mitigating asymmetric information.

We also provide evidences that pyramidal ownership seems to be a good instrument to reduce the use of internal funds on investment spending for both constrained and unconstrained firms. Besides, the negative effect of pyramid in investment-cash flow sensitivity seems not to be driven by family control or the level of divergence between voting rights and cash flow rights, refusing the idea that pyramid is due to tunneling activities. Since the long-term debt in Brazil is not widely available for all firms, pyramidal ownership can be a way to support investment decisions and alleviate financial constraint due to funds transference among firms in the pyramid chain (internal capital market). 
Overall, our paper sheds new light about the effect of family ownership and the business group in investment spending of firms from an emerging economy as Brazil. In addition, we highlight the importance to a priori distinguish firms according to the presence of finance constraint to better understand the relation between ownership structure and investment-cash flow sensitivity.

Appendix. Definition of variables used in the analyses

\begin{tabular}{|c|c|c|}
\hline I & Investment rate & $\left(K_{i t}-K_{i, t-1}\right) / K_{i, t-1}$ where $K$ is capital stock. \\
\hline $\mathrm{CF}$ & Cash flow & Net income + depreciation + amortization \\
\hline $\mathrm{D}$ & Total debt & $($ Long-term + short term debt)/Ki,t-1 \\
\hline SG & Sales growth & $($ Sit - Sit-1)/Sit-1, where $S$ is total sales \\
\hline Size & Firm’s size & Logarithm of total assets (TA) \\
\hline Dividend & Dividend payout & $=1$ if the firm pays and amount of dividend; 0 otherwise \\
\hline ROA & Return on assets & Net income/total assets \\
\hline $\mathrm{ROE}$ & Return on equity & Net income/stockholders’ equity \\
\hline FD & Family Dummy & $\begin{array}{l}=1 \text { if the largest ultimate shareholder is a family or individual; } 0 \\
\text { otherwise }\end{array}$ \\
\hline Board & Board Dummy & $\begin{array}{l}=1 \text { if the largest ultimate shareholder is a member of the board } \\
\text { of directors; } 0 \text { otherwise }\end{array}$ \\
\hline $\mathrm{CEO}$ & Management Dummy & $=1$ if the largest ultimate shareholder is the CEO; 0 otherwise \\
\hline PD & Pyramid Dummy & $=1$ if the firm belongs to pyramidal arrangements; 0 otherwise \\
\hline CG & Corporate Governance & $\begin{array}{l}=1 \text { if the firm is listed in one of three premium segments (Level } \\
1, \text { Level } 2, \text { Novo Mercado) and } 0 \text { otherwise }\end{array}$ \\
\hline Divergence & & $\begin{array}{l}\text { It is a continuous variable that measures the difference between } \\
\text { voting rights and cash flow rights of ultimate owner }\end{array}$ \\
\hline High_div & High divergence & $\begin{array}{l}=1 \text { if the largest shareholder shows higher divergence than the } \\
\text { sample median value; } 0 \text { otherwise }\end{array}$ \\
\hline Low_div & Low divergence & $\begin{array}{l}=1 \text { if the largest shareholder shows lower divergence than the } \\
\text { sample median value; } 0 \text { otherwise }\end{array}$ \\
\hline
\end{tabular}

\section{References}

Ağca, Ş., and A. Mozumdar. 2017. Investment-Cash Flow Sensitivity: Fact or Fiction? Journal of Financial and Quantitative Analysis. Vol. 52. doi:10.1017/S0022109017000230.

Almeida, H., M. Campello, and M.S. Weisbach. 2004. "The Cash Flow Sensitivity of Cash." Journal of Finance 59 (4): 1777-1804.

Almeida, H., S.Y. Park, M.G. Subrahmanyam, and D. Wolfenzon. 2011. "The Structure and Formation of Business Groups: Evidence from Korean Chaebols." Journal of Financial Economics 99 (2). North-Holland: 447-475. doi:10.1016/J.JFINECO.2010.08.017.

Almeida, H., and D. Wolfenzon. 2004. "A Theory of Pyramidal Ownership and Family Business Groups *."

Almeida, H., and D Wolfenzon. 2006. "A Theory of Pyramidal Ownership and Family Business Groups.” Journal of Finance 61 (6): 2637-2680. doi:10.1111/j.1540-6261.2006.01001.x.

Anderson, R.C., S.A. Mansi, and D.M. Reeb. 2003. "Founding Family Ownership and the Agency Cost of Debt." Journal of Financial Economics 68 (2). North-Holland: 263-285. doi:10.1016/S0304-405X(03)00067-9.

Anderson, R.C, and D.M. Reeb. 2003. "Founding-Family Ownership and Firm Performance: Evidence from the S\&amp;P 500." The Journal of Finance 58 (3): 1301-1328. doi:10.1111/1540-6261.00567.

Andres, C. 2011. "Family Ownership, Financing Constraints and Investment Decisions." Applied Financial Economics 21 (22): 1641-1659. doi:10.1080/09603107.2011.589805. 
Bertrand, M., P. Mehta, and S. Mullainathan. 2002. "Ferreting out Tunneling: An Application to Indian Business Groups*." The Quarterly Journal of Economics 117 (1): 121-148. doi:10.1162/003355302753399463.

Bond, S, and C Meghir. 1994. "Dynamic Investment Models and the Firm's Financial Policy." Review of Economic Studies 61 (2): 197-222.

Buchuk, D., B. Larrain, F. Muñoz, and F. Urzúa I. 2014. "The Internal Capital Markets of Business Groups : Evidence from Intra-Group Loans \$.” Journal of Financial Economics 112 (2). Elsevier: 190-212. doi:10.1016/j.jfineco.2014.01.003.

Caprio, L., E. Croci, and A.D. Giudice. 2011. "Ownership Structure , Family Control , and Acquisition Decisions.” Journal of Corporate Finance 17 (5). Elsevier B.V.: 1636-1657. doi:10.1016/j.jcorpfin.2011.09.008.

Carpenter, R. E, and A. Guariglia. 2003. Cash Flow, Investment, and Investment Opportunities. Nottingham: University of Nottingham, School of Economics.

Cho, My. 1998. "Ownership Structure, Investment, and the Corporate Value: An Empirical Analysis" 47: 103-121.

Claessens, S., S. Djankov, J.P.H Fan, and L.H.P. Lang. 2002. "Disentangling the Incentive and Entrenchment Effects of Large Shareholdings." Journal of Finance LVII (6): 2741-2771. doi:10.1111/1540-6261.00511.

Claessens, S. and B.B. Yurtoglu. 2013. "Corporate Governance in Emerging Markets: A Survey." Emerging Markets Review 15 (0): 1-33. doi:http://dx.doi.org/10.1016/j.ememar.2012.03.002.

Cleary, S. 1999. "The Relationship between Firm Investment and Financial Status." Journal of Finance 54 (2): 673-692. doi:10.1111/0022-1082.00121.

Cleary, S., P. Povel, and M. Raith. 2007. "The U-Shaped Investment Curve: Theory and Evidence." Journal of Financial \& Quantitative Analysis 42 (1): 1-39. doi:10.1017/S0022109000002179.

Crisóstomo, V.L., F.J López-Iturriaga, and E.V. González. 2014. "Nonfinancial Companies as Large Shareholders Alleviate Financial Constraints of Brazilian Firm." Emerging Markets Review 18 (March). North-Holland: 62-77. doi:10.1016/J.EMEMAR.2014.01.005.

Cucculelli, M., and V. Peruzzi. 2017. "Bank Screening Technologies and the Founder Effect: Evidence from European Lending Relationships" 20. Elsevier Inc.: 229-237. doi:10.1016/j.frl.2016.10.004.

Cucculelli, M., and V. Peruzzi. 2018. "Relational Capital in Lending Relationships : Evidence from European Family Firms." Small Business Economics.

de Almeida, J.R., and William Eid Jr. 2014. "Access to Finance, Working Capital Management and Company Value: Evidences from Brazilian Companies Listed on BM\&FBOVESPA." Journal of Business Research $67 \quad$ (5): $1924-934$. doi:http://dx.doi.org/10.1016/j.jbusres.2013.07.012.

Degryse, H, and A De Jong. 2006. "Investment and Internal Finance: Asymmetric Information or Managerial Discretion?” International Journal of Industrial Organization 24 (1): 125-147. doi:10.1016/j.ijindorg.2005.03.006.

Devereux, M, and F. Schiantarelli. 1990. "Investment, Financial Factors and Cash Flow: Evidence from UK Panel Data." Asymmetric Information, Corporate Finance, and Investment, 279306.

Faccio, M., and Larry H P Lang. 2002. "The Ultimate Ownership of Western European Corporations." Journal of Financial Economics 65 (3): 365-395. doi:10.1016/S0304405X(02)00146-0.

Fazzari, S. M, R Glenn Hubbard, and B. C Petersen. 1988. "Financing Corporate Constraints Investment." Brookings Papers on Economic Activity 1 (1): 141-206.

Francis, B., Iftekhar Hasan, L. Song, and Maya Waisman. 2012. "Corporate Governance and Investment-Cash Fl Ow Sensitivity: Evidence from Emerging Markets." Emerging Markets Review. Elsevier B.V. doi:10.1016/j.ememar.2012.08.002.

George, R., R. Kabir, and Jing Qian. 2011. "Investment-Cash Flow Sensitivity and Financing Constraints: New Evidence from Indian Business Group Firms." Journal of Multinational Financial Management 21 (2). Elsevier B.V.: 69-88. doi:10.1016/j.mulfin.2010.12.003.

Gilchrist, S, and C P Himmelberg. 1995. "Evidence on the Role of Cash Flow for Investment." 
Journal of Monetary Economics 36 (3): 541-572.

Gomes, J F. 2001. "Financing Investment." American Economic Review 91 (5): 1263-1285.

Gopalan, R., Vi. Nanda, and Amit Seru. 2014. "Internal Capital Market and Dividend Policies: Evidence From Business Groups." The Review of Financial Studies 27 (4): 1102-1142. doi:10.1093/rfs/hhu004.

Guariglia, Al.. 2008. "Internal Financial Constraints, External Financial Constraints, and Investment Choice: Evidence from a Panel of UK Firms." Journal of Banking and Finance 32 (9): 1795-1809. doi:10.1016/j.jbankfin.2007.12.008.

Gugler, K.. 2003. "Corporate Governance and Investment." International Journal of the Economics of Business 10 (3): 261-289. doi:10.1080/1357151032000126238.

Hadlock, C J, and J R Pierce. 2010. "New Evidence on Measuring Financial Constraints: Moving beyond the KZ Index." Review of Financial Studies 23 (5): 1909-1940.

He, Jia, Xinyang Mao, Oliver M. Rui, and Xiaolei Zha. 2013. "Business Groups in China." Journal of Corporate Finance 22 (September). North-Holland: 166-192. doi:10.1016/J.JCORPFIN.2013.05.001.

Hoshi, T, A Kashyap, and D Scharfstein. 1991. "Corporate Structure, Liquidity, and Investment: Evidence from Japanese Industrial Groups.” Quarterly Journal of Economics 106 (1): 33-60.

Hubbard, R G. 1998. "Capital-Market Imperfections and Investment." Journal of Economic Literature 36 (1): 193-225.

Hung, Jung-Hua, and Yi-Ping Kuo. 2011. "The Effect of Family Control on Investment-Cash Flow Sensitivity." Applied Financial Economics 21 (12): 897-904. doi:10.1080/09603107.2010.539533.

Jensen, C, and H Meckling. 1976. "Theory of the Firm : Managerial Behavior, Agency Costs and Ownership Structure." Journal of Financial Economics 3: 305-360. doi:10.1016/0304405X(76)90026-X.

Jensen, M.. 1986. "Agency Costs of Free Cash Flow, Corporate Finance, and Takeovers." American Economic Review 76 (2): 323-329.

Jensen, M. C, and W.H Meckling. 1976. "Theory of the Firm: Managerial Behavior , Agency Costs and Ownership Structure."

Johnson, S, R L La Porta, F Lopez-de-Silanes, and A Shleifer. 2000. "Tunneling." American Economic Review 90 (2): 22-27.

Kadapakkam, Palani-Rajan, P.C Kumar, and L.A. Riddick. 1998. "The Impact of Cash Flows and Firm Size on Investment: The International Evidence." Journal of Banking \& Finance 22 (3): 293-320. doi:10.1016/S0378-4266(97)00059-9.

Kalatzis, A E G, C.R. Azzoni, and J. A Achcar. 2008. "Financial Constraints and Investment Decisions: Evidence from a Highly Unstable Emerging Economy." Applied Economics 40 (11). Routledge: 1425-1434. doi:10.1080/00036840600771379.

Kalatzis, A E G, and C R Azzoni. 2009. "Investment Decisions in Troubled Times: A Bayesian Approach Applied to Brazilian Firms." International Journal of Production Economics 120 (2): 595-606. doi:http://dx.doi.org/10.1016/j.ijpe.2009.04.009.

Kaplan, S N, and L Zingales. 1997. "Do Investment-Cash Flow Sensitivities Provide Useful Measures of Financing Constraints?" Quarterly Journal of Economics 112 (1): 169-213.

Kato, H K, Uri Loewenstein, and Wenyuh Tsay. 2002. "Dividend Policy, Cash Flow, and Investment in Japan." Pacific-Basin Finance Journal 10 (4). North-Holland: 443-473. doi:10.1016/S0927-538X(02)00068-9.

Kuo, Yi-Ping, and Jung-Hua Hung. 2012. "Family Control and Investment-Cash Flow Sensitivity: Moderating Effects of Excess Control Rights and Board Independence." Corporate Governance: An International Review 20 (3): 253-266. doi:10.1111/j.14678683.2011.00899.x.

La Porta, R, F Lopez-De-Silanes, A Shleifer, and R Vishny. 2000. "Investor Protection and Corporate Governance." Journal of Financial Economics 58 (1-2): 3-27.

La Porta, R, Fl, Lopez-de-silanes, A Shleifer. 1999. "Corporate Ownership around the World" 54 (2): 471-517.

Lamont, O, C Polk, and J Saá-Requejo. 2001. "Financial Constraints and Stock Returns." Review of Financial Studies 14 (2): 529-554. 
Lensink, R, Remco van der Molen, and Shubashis Gangopadhyay. 2003. "Business Groups, Financing Constraints and Investment: The Case of India." The Journal of Development Studies 40 (2): 93-119. doi:10.1080/00220380412331293787.

Masulis, R W, P K Pham, and J Zein. 2011. "Family Business Groups around the World: Financing Advantages, Control Motivations, and Organizational Choices." Review of Financial Studies 24 (11): 3556-3600.

Pawlina, G, and L Renneboog. 2005. "Is Investment-Cash Flow Sensitivity Caused by Agency Costs or Asymmetric Information? Evidence from the UK." European Financial Management 11 (4): 483-513.

Peruzzi, V. 2017. "Does Family Ownership Structure Affect Investment-Cash Flow Sensitivity? Evidence from Italian SMEs." Applied Economics 49 (43). Routledge: 4378-4393. doi:10.1080/00036846.2017.1282147.

Pindado, J, and C De La Torre. 2009. "Effect of Ownership Structure on Underinvestment and Overinvestment: Empirical Evidence from Spain." Accounting and Finance 49 (2): 363-383. doi:10.1111/j.1467-629X.2008.00286.x.

Pindado, J, and C de la Torre. 2004. "Why Is Ownership Endogenous?" Applied Economics Letters 11 (14): 901-904. doi:10.1080/1350485042000267003.

Pindado, J, I Requejo, and Chabela de la Torre. 2011. "Family Control and Investment-cash Flow Sensitivity: Empirical Evidence from the Euro Zone." Journal of Corporate Finance 17 (5): 1389-1409. doi:http://dx.doi.org/10.1016/j.jcorpfin.2011.07.003.

Schaller, H. 1993. "Asymmetric Information, Liquidity Constraints, and Canadian Investment." Canadian Journal of Economics 26 (3): 552-574.

Schiantarelli, F. 1996. "Financial Constraints and Investment: Methodological Issues and International Evidence." Oxford Review of Economic Policy 12 (2): 70-89.

Shin, Hyun-Han, and Y S. Park. 1999. "Financing Constraints and Internal Capital Markets: Evidence from Korean 'chaebols'.” Journal of Corporate Finance 5 (2). North-Holland: 169191. doi:10.1016/S0929-1199(99)00002-4.

Shleifer, A, and R W Vishny. 1986. "Large Shareholders and Corporate Control" 94 (3): 461488.

Stulz, RenM. 1990. "Managerial Discretion and Optimal Financing Policies." Journal of Financial Economics 26 (1): 3-27.

Villalonga, B, and R Amit. 2006. "How Do Family Ownership, Control and Management Affect Firm Value?" Journal of Financial Economics 80 (2): 385-417.

Wang, Dechun. 2006. "Founding Family Ownership and Earnings Quality." Journal of Accounting Research 44 (3). Wiley Online Library: 619-656. doi:10.1111/j.1475679X.2006.00213.X.

Whited, T M, and G Wu. 2006. "Financial Constraints Risk." Review of Financial Studies 19 (2): 531-559. doi:10.1093/rfs/hhj012.

Wintoki, M Babajide, James S Linck, and Jeffry M Netter. 2012. "Endogeneity and the Dynamics of Internal Corporate Governance." Journal of Financial Economics 105 (3): 581-606. doi:http://dx.doi.org/10.1016/j.jfineco.2012.03.005. 
TABLE 1

Summary statistics

\begin{tabular}{|c|c|c|c|c|c|c|c|c|c|c|c|c|}
\hline \multirow{3}{*}{ Variables } & \multicolumn{2}{|c|}{ Total Sample } & \multicolumn{2}{|c|}{$\mathrm{KZ}_{\mathrm{FUC}}$} & \multicolumn{2}{|c|}{$\mathrm{KZ}_{\mathrm{FC}}$} & \multirow{2}{*}{$\begin{array}{c}\text { Difference } \\
\mathrm{KZ}\end{array}$} & \multicolumn{2}{|c|}{$\mathrm{WW}_{\mathrm{FUC}}$} & \multicolumn{2}{|c|}{$\mathrm{WW}_{\mathrm{FC}}$} & \multirow{2}{*}{$\begin{array}{c}\text { Difference } \\
\text { WW }\end{array}$} \\
\hline & Mean & S.D. & Mean & S.D. & Mean & S.D. & & Mean & S.D. & Mean & S.D. & \\
\hline & $(1)$ & & $(2)$ & & $(3)$ & & $(2)-(3)$ & $(4)$ & & $(5)$ & & $(4)-(5)$ \\
\hline \multicolumn{13}{|c|}{ Panel A: Financial variables } \\
\hline $\mathrm{I}_{\mathrm{i}, \mathrm{t}-1}$ & 0.01 & 0.26 & 0.03 & 0.24 & -0.02 & 0.26 & $0.05^{* * *}$ & 0.04 & 0.25 & 0.00 & 0.28 & $0.03^{*}$ \\
\hline $\mathrm{CF}$ & 0.16 & 0.36 & 0.36 & 0.31 & -0.02 & 0.34 & $0.38^{* * *}$ & 0.27 & 0.24 & 0.03 & 0.41 & $0.24^{* * *}$ \\
\hline SG & 0.10 & 0.37 & 0.13 & 0.38 & 0.09 & 0.37 & 0.04 & 0.17 & 0.47 & 0.05 & 0.30 & $0.12^{* * * *}$ \\
\hline Debt & 2.00 & 1.99 & 1.89 & 1.97 & 2.21 & 2.07 & $-0.32^{* *}$ & 1.68 & 1.68 & 2.37 & 2.28 & $-0.68^{* * *}$ \\
\hline TA & 3.16 & 5.88 & 4.17 & 6.64 & 3.27 & 6.00 & $0.90^{* *}$ & 7.15 & 7.93 & 0.46 & 0.82 & $6.69^{* * * *}$ \\
\hline ROA & -0.00 & 0.14 & 0.06 & 0.07 & -0.06 & 0.17 & $0.12^{* * *}$ & 0.05 & 0.06 & -0.05 & 0.17 & $0.10^{* * * *}$ \\
\hline ROE & 0.02 & 0.50 & 0.12 & 0.28 & -0.05 & 0.60 & $0.17^{* * * *}$ & 0.10 & 0.27 & -0.03 & 0.59 & $0.14^{* * *}$ \\
\hline \multicolumn{13}{|c|}{ Panel B: Corporate and ownership variables } \\
\hline Divergence & 0.23 & 0.22 & 0.23 & 0.21 & 0.27 & 0.22 & $-0.04^{* *}$ & 0.23 & 0.23 & 0.25 & 0.21 & $-0.02^{*}$ \\
\hline FD & 0.42 & 0.49 & 0.36 & 0.48 & 0.43 & 0.50 & $-0.08^{* *}$ & 0.27 & 0.45 & 0.57 & 0.50 & $-0.30^{* * *}$ \\
\hline Board & 0.54 & 0.50 & 0.50 & 0.50 & 0.53 & 0.50 & -0.02 & 0.40 & 0.49 & 0.71 & 0.45 & $-0.32^{* * *}$ \\
\hline CEO & 0.38 & 0.48 & 0.35 & 0.48 & 0.34 & 0.48 & 0.00 & 0.23 & 0.42 & 0.52 & 0.50 & $-0.30^{* * * *}$ \\
\hline $\mathrm{CG}$ & 0.08 & 0.28 & 0.12 & 0.33 & 0.08 & 0.26 & $0.05^{* *}$ & 0.16 & 0.37 & 0.03 & 0.17 & $0.13^{* * * *}$ \\
\hline PD & 0.63 & 0.48 & 0.63 & 0.48 & 0.64 & 0.48 & -0.01 & 0.69 & 0.46 & 0.61 & 0.49 & $0.08^{* *}$ \\
\hline Number of Obs & \multicolumn{2}{|c|}{2329} & \multicolumn{2}{|c|}{674} & \multicolumn{2}{|c|}{674} & 1348 & \multicolumn{2}{|c|}{840} & \multicolumn{2}{|c|}{839} & 1679 \\
\hline Number of firms & \multicolumn{2}{|c|}{399} & \multicolumn{2}{|c|}{181} & \multicolumn{2}{|c|}{212} & & \multicolumn{2}{|c|}{189} & \multicolumn{2}{|c|}{229} & \\
\hline
\end{tabular}

See appendix A for variables definitions. Panel A provides summary statistics for the sample employed in our analysis. The sample comprises 399 Brazilian public firms and cover 1997 trough 2007. ***, **, * indicate significance at 1\%, 5\% and $10 \%$, respectively. 
TABLE 2

The impact of family control in investment-cash flow sensitivity of Constrained firms

\begin{tabular}{|c|c|c|c|c|c|c|c|c|c|c|c|c|}
\hline \multirow{2}{*}{ Variables } & \multicolumn{6}{|c|}{$\mathrm{KZ}_{\mathrm{FC}}$} & \multicolumn{6}{|c|}{$\mathrm{WW}_{\mathrm{FC}}$} \\
\hline & (1a) & $(2 a)$ & $(3 a)$ & $(4 a)$ & $(5 a)$ & $(6 a)$ & (1b) & $(2 b)$ & $(3 b)$ & (4b) & $(5 \mathrm{~b})$ & (6b) \\
\hline \multirow[t]{2}{*}{$\mathrm{CF}$} & $0.15 * *$ & $0.20 * *$ & $0.29 * * *$ & $0.26 * * *$ & $0.26 * * *$ & $0.24 * * *$ & 0.09 & $0.14^{* * *}$ & $0.12 * *$ & $0.11 *$ & $0.14 * *$ & $0.12 *$ \\
\hline & $(0.07)$ & $(0.08)$ & $(0.07)$ & $(0.06)$ & $(0.07)$ & $(0.07)$ & $(0.07)$ & $(0.05)$ & $(0.05)$ & $(0.06)$ & $(0.05)$ & $(0.07)$ \\
\hline \multirow[t]{2}{*}{ FD } & & 0.07 & & $0.28 *$ & & 0.09 & & 0.06 & & -0.03 & & 0.08 \\
\hline & & $(0.08)$ & & $(0.17)$ & & $(0.10)$ & & $(0.10)$ & & $(0.11)$ & & $(0.12)$ \\
\hline \multirow[t]{2}{*}{$\mathrm{CF}^{*} \mathrm{FD}$} & & -0.10 & & 0.31 & & $0.29 *$ & & -0.03 & & 0.22 & & 0.14 \\
\hline & & $(0.08)$ & & $(0.31)$ & & $(0.15)$ & & $(0.10)$ & & $(0.23)$ & & $(0.10)$ \\
\hline \multirow[t]{2}{*}{ Board } & & & 0.03 & 0.05 & & & & & -0.06 & -0.16 & & \\
\hline & & & $(0.10)$ & $(0.10)$ & & & & & $(0.09)$ & $(0.11)$ & & \\
\hline \multirow[t]{2}{*}{ FC*Board } & & & $-0.21 * *$ & $-0.37 * *$ & & & & & -0.03 & 0.12 & & \\
\hline & & & $(0.08)$ & $(0.15)$ & & & & & $(0.07)$ & $(0.16)$ & & \\
\hline \multirow[t]{2}{*}{ Board*FD } & & & & -0.28 & & & & & & 0.19 & & \\
\hline & & & & $(0.18)$ & & & & & & $(0.15)$ & & \\
\hline \multirow[t]{2}{*}{ CF*Board*FD } & & & & -0.10 & & & & & & -0.37 & & \\
\hline & & & & $(0.38)$ & & & & & & $(0.31)$ & & \\
\hline \multirow[t]{2}{*}{ CEO } & & & & & -0.09 & $-0.18^{*}$ & & & & & -0.15 & $-0.26^{* *}$ \\
\hline & & & & & $(0.12)$ & $(0.11)$ & & & & & $(0.10)$ & $(0.12)$ \\
\hline \multirow[t]{2}{*}{$\mathrm{CF}^{*} \mathrm{CEO}$} & & & & & $-0.25 * * *$ & -0.07 & & & & & -0.07 & 0.15 \\
\hline & & & & & $(0.09)$ & $(0.32)$ & & & & & $(0.11)$ & $(0.18)$ \\
\hline \multirow[t]{2}{*}{ CEO*FD } & & & & & & 0.08 & & & & & & 0.10 \\
\hline & & & & & & $(0.15)$ & & & & & & $(0.16)$ \\
\hline \multirow[t]{2}{*}{$\mathrm{CF} * \mathrm{CEO} * \mathrm{FD}$} & & & & & & -0.43 & & & & & & -0.32 \\
\hline & & & & & & $(0.37)$ & & & & & & $(0.24)$ \\
\hline \multirow[t]{2}{*}{$\mathrm{CG}$} & & $0.12 *$ & 0.08 & 0.10 & 0.08 & 0.08 & & 0.06 & 0.07 & 0.08 & 0.10 & $0.16^{* *}$ \\
\hline & & $(0.07)$ & $(0.09)$ & $(0.09)$ & $(0.08)$ & $(0.07)$ & & $(0.07)$ & $(0.06)$ & $(0.07)$ & $(0.10)$ & $(0.07)$ \\
\hline \multirow[t]{2}{*}{ Divergence } & & -0.24 & -0.17 & $-0.27 *$ & -0.13 & $-0.24^{*}$ & & $-0.51 * *$ & $-0.48 * * *$ & $-0.55 * * *$ & -0.23 & $-0.37 * *$ \\
\hline & & $(0.16)$ & $(0.16)$ & $(0.14)$ & $(0.17)$ & $(0.14)$ & & $(0.20)$ & $(0.19)$ & $(0.21)$ & $(0.21)$ & $(0.16)$ \\
\hline \multirow[t]{2}{*}{$\left(\mathrm{I}_{\mathrm{i}, \mathrm{t}-1}\right)$} & -0.18 & $-0.22 * *$ & $-0.19 * *$ & $-0.22 * *$ & $-0.23^{* *}$ & $-0.22 * *$ & -0.12 & -0.12 & -0.09 & -0.09 & -0.02 & -0.02 \\
\hline & $(0.11)$ & $(0.09)$ & $(0.09)$ & $(0.09)$ & $(0.10)$ & $(0.09)$ & $(0.15)$ & $(0.13)$ & $(0.12)$ & $(0.13)$ & $(0.13)$ & $(0.10)$ \\
\hline \multirow[t]{2}{*}{$\left(\mathrm{I}_{\mathrm{i}, \mathrm{t}-1}\right)^{2}$} & 0.13 & $0.16 * *$ & $0.14^{*}$ & $0.16 * *$ & $0.16^{*}$ & $0.16^{* *}$ & 0.09 & 0.10 & 0.06 & 0.07 & -0.01 & -0.01 \\
\hline & $(0.09)$ & $(0.07)$ & $(0.08)$ & $(0.07)$ & (0.09) & $(0.07)$ & $(0.12)$ & $(0.11)$ & (0.09) & $(0.11)$ & $(0.10)$ & $(0.08)$ \\
\hline \multirow[t]{2}{*}{ SG } & 0.02 & 0.02 & 0.01 & 0.02 & 0.03 & 0.02 & -0.04 & -0.03 & -0.03 & -0.03 & -0.04 & -0.01 \\
\hline & $(0.05)$ & $(0.05)$ & $(0.04)$ & $(0.05)$ & $(0.06)$ & $(0.05)$ & $(0.06)$ & $(0.06)$ & $(0.05)$ & $(0.06)$ & $(0.06)$ & $(0.06)$ \\
\hline
\end{tabular}




\begin{tabular}{|c|c|c|c|c|c|c|c|c|c|c|c|c|}
\hline Debt & $\begin{array}{c}0.16 * * * \\
(0.05)\end{array}$ & $\begin{array}{c}0.14 * * * \\
(0.03)\end{array}$ & $\begin{array}{c}0.16 * * * \\
(0.04)\end{array}$ & $\begin{array}{c}0.14 * * * \\
(0.03)\end{array}$ & $\begin{array}{c}0.16 * * * \\
(0.04)\end{array}$ & $\begin{array}{c}0.14 * * * \\
(0.03)\end{array}$ & $\begin{array}{c}0.14 * * * \\
(0.03)\end{array}$ & $\begin{array}{c}0.12 * * * \\
(0.02)\end{array}$ & $\begin{array}{c}0.11 * * * \\
(0.02)\end{array}$ & $\begin{array}{c}0.12 * * * \\
(0.03)\end{array}$ & $\begin{array}{c}0.12 * * * \\
(0.03)\end{array}$ & $\begin{array}{c}0.10 * * * \\
(0.02)\end{array}$ \\
\hline \multirow[t]{2}{*}{ Size } & $-0.21 * * *$ & -0.04 & $-0.05^{*}$ & -0.03 & $-0.09 * *$ & -0.04 & -0.10 & -0.02 & -0.05 & -0.03 & $-0.09 *$ & -0.05 \\
\hline & $(0.07)$ & $(0.03)$ & $(0.03)$ & $(0.02)$ & $(0.04)$ & $(0.03)$ & $(0.06)$ & $(0.04)$ & $(0.04)$ & $(0.05)$ & $(0.06)$ & $(0.05)$ \\
\hline \multirow[t]{2}{*}{ Constant } & $2.36^{* *}$ & 0.06 & 0.29 & -0.06 & 0.74 & 0.17 & 0.73 & -0.10 & 0.38 & 0.14 & 0.85 & 0.45 \\
\hline & $(0.93)$ & $(0.41)$ & $(0.45)$ & $(0.33)$ & $(0.55)$ & $(0.40)$ & $(0.76)$ & $(0.56)$ & $(0.52)$ & $(0.60)$ & $(0.71)$ & $(0.59)$ \\
\hline Observations & 528 & 519 & 519 & 518 & 519 & 518 & 623 & 611 & 609 & 609 & 611 & 611 \\
\hline Year effect & Yes & Yes & Yes & Yes & Yes & Yes & Yes & Yes & Yes & Yes & Yes & Yes \\
\hline $\mathrm{AR}(2)$ & 0.354 & -0.262 & 0.0269 & 0.883 & -0.286 & -0.398 & -0.556 & -0.200 & -0.130 & -0.547 & 0.0908 & 0.246 \\
\hline Sargan test & 61.05 & 89.72 & 88.87 & 113.9 & 89.46 & 108.6 & 54.69 & 81.08 & 77.50 & 89.51 & 80.07 & 106.4 \\
\hline p-value Sargan & 0.183 & 0.262 & 0.283 & 0.306 & 0.244 & 0.439 & 0.373 & 0.477 & 0.620 & 0.843 & 0.508 & 0.525 \\
\hline
\end{tabular}

for variables definitions. The sample comprises 399 Brazilian public firms and cover 1997 through 2007 . ***, **, * indicate significance at $1 \%, 5 \%$ and $10 \%$, respectively. 
TABLE 3

The impact of family control in investment-cash flow sensitivity of Unconstrained firms

\begin{tabular}{|c|c|c|c|c|c|c|c|c|c|c|c|c|}
\hline \multirow{2}{*}{ Variables } & \multicolumn{6}{|c|}{$\mathrm{KZ}_{\mathrm{FUC}}$} & \multicolumn{6}{|c|}{$\mathrm{WW}_{\mathrm{FUC}}$} \\
\hline & (1a) & $(2 a)$ & $(3 a)$ & (4a) & $(5 a)$ & (6a) & $(1 \mathrm{~b})$ & $(2 b)$ & $(3 b)$ & $(4 b)$ & $(5 b)$ & $(6 b)$ \\
\hline \multirow[t]{2}{*}{$\mathrm{CF}$} & $0.15 * *$ & $0.21 * *$ & 0.15 & 0.15 & 0.09 & 0.16 & $0.25 * *$ & 0.25 & 0.26 & $0.28 *$ & 0.16 & 0.24 \\
\hline & $(0.07)$ & $(0.10)$ & $(0.12)$ & $(0.14)$ & $(0.08)$ & $(0.10)$ & $(0.11)$ & $(0.16)$ & $(0.16)$ & $(0.16)$ & $(0.11)$ & $(0.17)$ \\
\hline \multirow[t]{2}{*}{ FD } & & $0.18 * *$ & & $0.39 *$ & & $0.17 * *$ & & 0.15 & & $0.36^{* * *}$ & & $0.25 * *$ \\
\hline & & $(0.09)$ & & $(0.23)$ & & $(0.08)$ & & $(0.12)$ & & $(0.13)$ & & $(0.11)$ \\
\hline \multirow[t]{2}{*}{$\mathrm{CF}^{*} \mathrm{FD}$} & & $-0.23^{*}$ & & $-1.15^{*}$ & & $-0.27 *$ & & -0.22 & & $-1.06 * * *$ & & $-0.47 *$ \\
\hline & & $(0.13)$ & & $(0.69)$ & & $(0.16)$ & & $(0.24)$ & & $(0.34)$ & & $(0.24)$ \\
\hline \multirow[t]{2}{*}{ Board } & & & 0.10 & 0.13 & & & & & 0.13 & 0.20 & & \\
\hline & & & $(0.10)$ & $(0.15)$ & & & & & $(0.12)$ & $(0.14)$ & & \\
\hline \multirow[t]{2}{*}{ FC*Board } & & & -0.15 & -0.19 & & & & & -0.18 & -0.43 & & \\
\hline & & & $(0.13)$ & $(0.19)$ & & & & & $(0.23)$ & $(0.30)$ & & \\
\hline \multirow[t]{2}{*}{ Board*FD } & & & & -0.39 & & & & & & $-0.45 * * *$ & & \\
\hline & & & & $(0.28)$ & & & & & & $(0.17)$ & & \\
\hline \multirow[t]{2}{*}{ CF*Board*FD } & & & & $1.21 *$ & & & & & & $1.31 * * *$ & & \\
\hline & & & & $(0.71)$ & & & & & & $(0.46)$ & & \\
\hline \multirow[t]{2}{*}{ CEO } & & & & & -0.07 & -0.01 & & & & & 0.07 & 0.10 \\
\hline & & & & & $(0.08)$ & (0.09) & & & & & $(0.11)$ & $(0.10)$ \\
\hline \multirow[t]{2}{*}{$\mathrm{CF}^{*} \mathrm{CEO}$} & & & & & 0.06 & -0.10 & & & & & -0.32 & -0.43 \\
\hline & & & & & $(0.14)$ & $(0.16)$ & & & & & $(0.20)$ & $(0.26)$ \\
\hline \multirow[t]{2}{*}{ CEO*FD } & & & & & & -0.13 & & & & & & -0.20 \\
\hline & & & & & & $(0.15)$ & & & & & & $(0.22)$ \\
\hline \multirow[t]{2}{*}{ CF*CEO*FD } & & & & & & 0.35 & & & & & & $0.56^{*}$ \\
\hline & & & & & & $(0.24)$ & & & & & & $(0.33)$ \\
\hline \multirow[t]{2}{*}{ CG } & & 0.04 & 0.05 & 0.04 & 0.10 & 0.06 & & 0.00 & 0.01 & 0.02 & 0.02 & -0.00 \\
\hline & & $(0.06)$ & $(0.06)$ & $(0.06)$ & $(0.07)$ & $(0.06)$ & & $(0.05)$ & $(0.05)$ & $(0.05)$ & $(0.05)$ & $(0.05)$ \\
\hline \multirow[t]{2}{*}{ Divergence } & & -0.18 & -0.02 & -0.12 & 0.08 & -0.07 & & -0.10 & -0.09 & -0.04 & 0.01 & 0.04 \\
\hline & & $(0.18)$ & $(0.18)$ & $(0.14)$ & $(0.18)$ & $(0.15)$ & & $(0.21)$ & $(0.17)$ & (0.19) & $(0.15)$ & $(0.17)$ \\
\hline \multirow[t]{2}{*}{$\mathrm{I}_{\mathrm{i}, \mathrm{t}-1}$} & -0.04 & -0.04 & -0.03 & -0.04 & -0.00 & -0.01 & -0.14 & -0.07 & -0.17 & -0.12 & -0.14 & -0.11 \\
\hline & (0.09) & $(0.10)$ & $(0.09)$ & (0.09) & $(0.10)$ & (0.09) & $(0.14)$ & $(0.13)$ & $(0.15)$ & $(0.14)$ & $(0.17)$ & $(0.10)$ \\
\hline \multirow[t]{2}{*}{$\left(\mathrm{I}_{\mathrm{i}, \mathrm{t}-1}\right)^{2}$} & -0.03 & -0.04 & -0.09 & -0.09 & -0.13 & -0.14 & 0.08 & -0.05 & 0.06 & 0.00 & 0.05 & 0.02 \\
\hline & $(0.11)$ & $(0.12)$ & $(0.10)$ & $(0.10)$ & $(0.10)$ & $(0.10)$ & $(0.11)$ & $(0.12)$ & $(0.10)$ & $(0.12)$ & $(0.11)$ & $(0.09)$ \\
\hline \multirow[t]{2}{*}{ SG } & $0.17 * * *$ & $0.21 * * *$ & $0.21 * * *$ & $0.24 * * *$ & $0.23^{* * *}$ & $0.24 * * *$ & 0.08 & $0.17 * *$ & $0.15^{* *}$ & $0.18^{* *}$ & $0.16^{* *}$ & $0.16^{* *}$ \\
\hline & $(0.04)$ & $(0.06)$ & $(0.07)$ & $(0.06)$ & $(0.06)$ & $(0.07)$ & $(0.06)$ & $(0.07)$ & $(0.07)$ & $(0.07)$ & $(0.08)$ & $(0.08)$ \\
\hline
\end{tabular}




\begin{tabular}{|c|c|c|c|c|c|c|c|c|c|c|c|c|}
\hline Debt & $\begin{array}{c}0.10 * * \\
(0.04)\end{array}$ & $\begin{array}{c}0.10 * * \\
(0.05)\end{array}$ & $\begin{array}{c}0.09 * * \\
(0.04)\end{array}$ & $\begin{array}{c}0.09 * * \\
(0.04)\end{array}$ & $\begin{array}{c}0.08 * * \\
(0.04)\end{array}$ & $\begin{array}{c}0.08 * * \\
(0.04)\end{array}$ & $\begin{array}{c}0.18 * * * \\
(0.05)\end{array}$ & $\begin{array}{c}0.13 * * * \\
(0.04)\end{array}$ & $\begin{array}{c}0.13 * * * \\
(0.05)\end{array}$ & $\begin{array}{c}0.13 * * * \\
(0.04)\end{array}$ & $\begin{array}{c}0.14 * * * \\
(0.05)\end{array}$ & $\begin{array}{c}0.14 * * * \\
(0.05)\end{array}$ \\
\hline \multirow[t]{2}{*}{ Size } & -0.01 & -0.00 & -0.01 & -0.00 & -0.02 & -0.01 & $-0.30 * * *$ & $-0.21 * * *$ & $-0.17 * * *$ & $-0.15 * * *$ & $-0.15 * * *$ & $-0.13 * * *$ \\
\hline & $(0.04)$ & $(0.03)$ & $(0.03)$ & $(0.03)$ & $(0.02)$ & $(0.02)$ & $(0.08)$ & $(0.07)$ & $(0.05)$ & $(0.05)$ & $(0.05)$ & $(0.04)$ \\
\hline \multirow[t]{2}{*}{ Constant } & -0.07 & -0.19 & 0.02 & -0.18 & 0.14 & -0.04 & $4.19 * * *$ & $2.90 * * *$ & $2.31 * * *$ & $2.01 * * *$ & $2.04 * * *$ & $1.61 * * *$ \\
\hline & $(0.62)$ & $(0.52)$ & $(0.53)$ & $(0.48)$ & $(0.38)$ & (0.39) & $(1.12)$ & $(1.00)$ & $(0.77)$ & $(0.77)$ & $(0.76)$ & $(0.62)$ \\
\hline Observations & 554 & 549 & 548 & 548 & 549 & 549 & 725 & 718 & 718 & 717 & 718 & 717 \\
\hline Year effect & Yes & Yes & Yes & Yes & Yes & Yes & Yes & Yes & Yes & Yes & Yes & Yes \\
\hline $\operatorname{AR}(2)$ & -0.116 & 0.246 & -0.264 & -0.298 & -0.108 & 0.118 & -0.216 & -1.206 & -1.425 & -0.999 & -1.446 & -1.166 \\
\hline Sargan test & 63.35 & 85.70 & 87.71 & 95.63 & 90.47 & 108.0 & 64.86 & 97.81 & 93.06 & 113.1 & 97.34 & 117.6 \\
\hline p-value Sargan & 0.293 & 0.489 & 0.428 & 0.755 & 0.407 & 0.563 & 0.250 & 0.223 & 0.336 & 0.585 & 0.233 & 0.442 \\
\hline
\end{tabular}

This table reports the estimation results of eq(3) for unconstrained firms using the System-GMM estimator. Robust standard errors are shown in parentheses. See appendix A

for variables definitions. The sample comprises 399 Brazilian public firms and cover 1997 through 2007 . ***, **, * indicate significance at $1 \%$, 5\% and $10 \%$, respectively. 
TABLE 4

The effect of family-pyramidal ownership in investment-cash flow sensitivity

\begin{tabular}{|c|c|c|c|c|c|c|c|c|c|c|c|c|}
\hline \multirow{3}{*}{ Variables } & \multicolumn{6}{|c|}{ Constrained firms } & \multicolumn{6}{|c|}{ Unconstrained frms } \\
\hline & \multicolumn{3}{|c|}{$\mathrm{KZ}_{\mathrm{FC}}$} & \multicolumn{3}{|c|}{$\mathrm{WW}_{\mathrm{FC}}$} & \multicolumn{3}{|c|}{$\mathrm{KZ}_{\mathrm{FUC}}$} & \multicolumn{3}{|c|}{$\mathrm{WW}_{\mathrm{FUC}}$} \\
\hline & (1a) & $(2 a)$ & $(3 a)$ & $(4 a)$ & $(5 a)$ & (6a) & (1b) & $(2 b)$ & $(3 b)$ & (4b) & $(5 b)$ & (6b) \\
\hline \multirow[t]{2}{*}{$\mathrm{CF}$} & $0.25 * * *$ & $0.25 * * *$ & $0.25 * * *$ & $0.11^{*}$ & 0.08 & 0.09 & 0.20 & $0.25^{*}$ & $0.23 *$ & $0.50 * *$ & $0.53 * *$ & $0.65 * * *$ \\
\hline & $(0.08)$ & $(0.08)$ & $(0.08)$ & $(0.07)$ & $(0.07)$ & $(0.06)$ & $(0.15)$ & $(0.13)$ & $(0.12)$ & $(0.20)$ & $(0.22)$ & $(0.25)$ \\
\hline \multirow[t]{2}{*}{ PD } & 0.11 & & & 0.10 & & & 0.14 & & & $0.22 * *$ & & \\
\hline & $(0.10)$ & & & $(0.09)$ & & & (0.09) & & & $(0.10)$ & & \\
\hline \multirow[t]{2}{*}{$\mathrm{CF}^{*} \mathrm{PD}$} & $-0.17 * *$ & & & 0.07 & & & -0.18 & & & $-0.44^{*}$ & & \\
\hline & $(0.09)$ & & & $(0.10)$ & & & $(0.19)$ & & & $(0.24)$ & & \\
\hline \multirow[t]{2}{*}{$\mathrm{PD} * \mathrm{FD}$} & & 0.08 & & & 0.10 & & & $0.24 * * *$ & & & $0.30 * *$ & \\
\hline & & $(0.11)$ & & & $(0.09)$ & & & $(0.09)$ & & & $(0.12)$ & \\
\hline \multirow[t]{2}{*}{$\mathrm{CF} * \mathrm{PD} * \mathrm{FD}$} & & -0.12 & & & 0.07 & & & $-0.36 * *$ & & & $-0.55^{* *}$ & \\
\hline & & $(0.10)$ & & & $(0.10)$ & & & $(0.17)$ & & & $(0.26)$ & \\
\hline \multirow[t]{2}{*}{ PD*(1-FD) } & & 0.08 & 0.11 & & 0.10 & 0.09 & & 0.11 & 0.10 & & $0.26 * *$ & $0.33^{* *}$ \\
\hline & & $(0.10)$ & $(0.08)$ & & $(0.10)$ & $(0.09)$ & & $(0.08)$ & $(0.08)$ & & $(0.11)$ & $(0.13)$ \\
\hline \multirow[t]{2}{*}{$C F * P D *(1-F D)$} & & $-0.21 *$ & $-0.21 * *$ & & 0.15 & 0.13 & & -0.12 & -0.08 & & $-0.48^{*}$ & $-0.61 *$ \\
\hline & & $(0.11)$ & $(0.09)$ & & $(0.15)$ & $(0.14)$ & & $(0.19)$ & $(0.18)$ & & $(0.27)$ & $(0.32)$ \\
\hline \multirow[t]{2}{*}{ PD*FD*(High_div) } & & & 0.08 & & & 0.05 & & & $0.21 * *$ & & & $0.30 * * *$ \\
\hline & & & $(0.13)$ & & & $(0.13)$ & & & $(0.09)$ & & & $(0.11)$ \\
\hline \multirow{2}{*}{ CF*PD*FD*(High_div) } & & & -0.16 & & & 0.04 & & & $-0.33^{*}$ & & & $-0.63 * * *$ \\
\hline & & & $(0.11)$ & & & $(0.10)$ & & & $(0.18)$ & & & $(0.23)$ \\
\hline \multirow[t]{2}{*}{ PD*FD*(Low_div) } & & & $0.21 *$ & & & 0.12 & & & $0.22 * *$ & & & $0.52 * * *$ \\
\hline & & & $(0.12)$ & & & $(0.09)$ & & & $(0.09)$ & & & $(0.17)$ \\
\hline \multirow[t]{2}{*}{ CF*PD*FD*(Low_div) } & & & 0.07 & & & 0.21 & & & -0.29 & & & $-0.80 * *$ \\
\hline & & & $(0.14)$ & & & $(0.13)$ & & & $(0.18)$ & & & $(0.39)$ \\
\hline \multirow[t]{2}{*}{$\mathrm{I}_{\mathrm{i}, \mathrm{t}-1}$} & $-0.18 *$ & $-0.20 *$ & $-0.19 * *$ & -0.02 & -0.04 & -0.03 & 0.01 & -0.01 & 0.01 & -0.21 & -0.13 & -0.12 \\
\hline & $(0.10)$ & $(0.10)$ & $(0.09)$ & $(0.10)$ & $(0.11)$ & $(0.12)$ & $(0.10)$ & $(0.08)$ & $(0.08)$ & $(0.14)$ & $(0.13)$ & $(0.13)$ \\
\hline \multirow[t]{2}{*}{$\left(\mathrm{I}_{\mathrm{i}, \mathrm{t}-1}\right)^{2}$} & 0.12 & $0.13^{*}$ & $0.13^{*}$ & 0.02 & 0.03 & 0.02 & -0.13 & -0.09 & -0.10 & 0.09 & 0.01 & -0.01 \\
\hline & $(0.08)$ & $(0.08)$ & $(0.07)$ & $(0.09)$ & (0.09) & $(0.10)$ & $(0.12)$ & $(0.11)$ & $(0.11)$ & $(0.10)$ & $(0.10)$ & $(0.11)$ \\
\hline \multirow[t]{2}{*}{ SG } & 0.04 & 0.03 & 0.02 & -0.04 & -0.06 & -0.09 & $0.21 * * *$ & $0.23 * * *$ & $0.23 * * *$ & $0.15^{*}$ & $0.15^{* *}$ & $0.18^{* *}$ \\
\hline & $(0.05)$ & $(0.06)$ & $(0.05)$ & $(0.07)$ & $(0.07)$ & $(0.06)$ & $(0.07)$ & $(0.06)$ & $(0.06)$ & $(0.07)$ & $(0.08)$ & $(0.09)$ \\
\hline \multirow[t]{2}{*}{ Debt } & $0.15^{* * *}$ & $0.15^{* * *}$ & $0.14 * * *$ & $0.13 * * *$ & $0.13 * * *$ & $0.12 * * *$ & $0.08^{*}$ & $0.08 * *$ & $0.09 * *$ & $0.13 * * *$ & $0.11 * * *$ & $0.10^{*}$ \\
\hline & $(0.04)$ & $(0.04)$ & $(0.04)$ & $(0.02)$ & $(0.03)$ & $(0.03)$ & $(0.04)$ & $(0.04)$ & $(0.04)$ & $(0.04)$ & $(0.04)$ & $(0.05)$ \\
\hline Size & $-0.09 * *$ & $-0.06^{* *}$ & -0.02 & -0.02 & -0.03 & -0.04 & -0.01 & 0.00 & -0.00 & $-0.15^{* * *}$ & $-0.13^{* *}$ & $-0.12 * *$ \\
\hline
\end{tabular}




\begin{tabular}{|c|c|c|c|c|c|c|c|c|c|c|c|c|}
\hline & $(0.04)$ & $(0.03)$ & $(0.02)$ & $(0.04)$ & $(0.04)$ & $(0.03)$ & $(0.02)$ & $(0.02)$ & $(0.02)$ & $(0.06)$ & $(0.06)$ & $(0.05)$ \\
\hline \multirow[t]{2}{*}{ Divergence } & -0.24 & -0.25 & -0.16 & $-0.52 * * *$ & $-0.45 * *$ & $-0.34^{*}$ & -0.08 & -0.17 & -0.16 & -0.09 & -0.05 & 0.08 \\
\hline & $(0.20)$ & $(0.16)$ & $(0.16)$ & $(0.20)$ & $(0.19)$ & $(0.20)$ & $(0.18)$ & $(0.15)$ & $(0.15)$ & $(0.17)$ & $(0.16)$ & $(0.15)$ \\
\hline \multirow[t]{2}{*}{ CG } & $0.13 *$ & $0.13 * *$ & $0.14^{* *}$ & $0.11 *$ & 0.08 & 0.09 & 0.09 & 0.06 & 0.07 & 0.03 & 0.04 & 0.04 \\
\hline & $(0.07)$ & $(0.06)$ & $(0.07)$ & $(0.06)$ & $(0.07)$ & $(0.08)$ & $(0.07)$ & $(0.06)$ & $(0.06)$ & $(0.06)$ & $(0.06)$ & $(0.05)$ \\
\hline \multirow[t]{2}{*}{ Constant } & 0.74 & 0.42 & -0.22 & -0.13 & -0.06 & 0.44 & -0.04 & -0.28 & -0.22 & $2.00 * *$ & $1.57 *$ & $1.30 *$ \\
\hline & $(0.53)$ & $(0.37)$ & $(0.30)$ & $(0.51)$ & $(0.44)$ & $(0.41)$ & $(0.42)$ & $(0.42)$ & $(0.40)$ & $(0.84)$ & $(0.85)$ & $(0.67)$ \\
\hline Observations & 520 & 519 & 519 & 611 & 611 & 611 & 549 & 549 & 549 & 718 & 717 & 717 \\
\hline Year effect & Yes & Yes & Yes & Yes & Yes & Yes & Yes & Yes & Yes & Yes & Yes & Yes \\
\hline $\mathrm{AR}(2)$ & 0.264 & 0.502 & 0.345 & -0.0372 & -0.264 & -0.267 & -0.189 & 0.0454 & 0.0867 & -1.262 & -1.210 & -1.449 \\
\hline Sargan & 92.91 & 104.3 & 114.3 & 92.17 & 105.6 & 119.8 & 94.63 & 102.1 & 102.7 & 95.42 & 115.4 & 126.1 \\
\hline p-value Sargan & 0.340 & 0.419 & 0.395 & 0.359 & 0.385 & 0.362 & 0.295 & 0.478 & 0.724 & 0.276 & 0.189 & 0.226 \\
\hline
\end{tabular}

This table reports the estimation results of eq(4) using the System-GMM estimator. Robust standard errors are shown in parentheses. See appendix A for variables

definitions. The sample comprises 399 Brazilian public firms and cover 1997 through $2007 . * * *, * *, *$ indicate significance at 1\%, 5\% and 10\%, respectively. 